\title{
Analysis of Discourse from Perspective of Systemic Functional Grammar*
}

\author{
Xiaqing Li \\ Department of Minority Languages and Literatures, Minzu University of China, Beijing, China
}

\begin{abstract}
Firstly the author introduces Systemic Functional Grammar in this paper, including the levels of language and their realization relationships, the systems of the three metafunctions and their submetafunctions, as well as the two levels of discourse analysis(DA). Then being based on different aspects of the systemic functional grammar, this paper analyzes the four discourses. Person system, mood and modality system, cohesion system in systemic function grammar are used in analysis of the first discourse "heal the world" which reveals some features of discourse of song. Understanding these characteristics can deepen understanding of the listener to the discourse of English song so as to improve the listener's ability to appreciate the song. When analyzing the other three discourses, the author uses the "context-text-commentary" method. Elaborate applicability of this linguistic theory to DA is the purpose. Finally, concluding that analysis of discourse with the systemic functional grammar analysis is not only a good way, but also it has very important significance.
\end{abstract}

Index Terms - Systemic Functional Grammar, levels of language, discourse analysis, method of analysis, person system

\section{INTRODUCTION}

After Huang Guowen successfully applied the framework of Systemic Functional Grammar to analyze advertising discourse and pointed out that "this grammar is more suitable for the analysis of discourse than any other linguistic frame". (Huang Guowen, 2001) This is because the system itself is a discourse-functional grammar, and its grammatical category can be interpreted as the realization of the semantic paradigm, that is "its grammatical forms naturally associated with coding significance. (Halliday, 1994) This discourse grammar clearly describes the various levels of language and relations among them; this is because the grammar is used to illustrate how language is used, and that is "it offers the method of insight into the meaning of discourse and the effectiveness of discourse ; this is because the systematic functional grammar clearly describes three metafunction network systems of language, and as well as the concepts of their subsystems and possibility of the application of them; it also because it clearly outlines levels and steps of discourse analysis, and the application of this grammatical framework for analyzing discourse allows us to avoid making only subjective and casual comment on discourse. There are two purposes for writing this article: one is that "further demonstrate applicability of systematic functional grammar in discourse analysis; the other is that "propose a more practical method or procedure of application of this grammatical framework for analyzing discourse. The following the author will firstly discuss the main theoretical aspects of the systemic functional grammar: levels of language and the relationships among them (Halliday, 1994) and that "context - text - commentary" discourse analysis approach, and functions related to the system will be mentioned in the process of analysis; and finally illustrate the value of systemic functional grammar in terms of discourse analysis.

\section{THEORETICAL REVIEW}

\section{A. Introduction to the Systemic Functional Grammar}

Systemic functional grammar (SFG) is a form of grammatical description originated by Michael Halliday(Halliday, 2011). It is part of a social semiotic approach to language called systemic functional linguistics. In these two terms, systemic refers to the view of language as "a network of systems, or interrelated sets of options for making meaning"(Halliday, 1994); function refers to Halliday's view that language is as it is because of what it has evolved to do. Thus, what he refers to as the multidimensional architecture of language "reflects the multidimensional nature of human experience and interpersonal relations."(Halliday, 2003) (Systemic Functional Grammar. https://wenku.baidu.com/view/912fb66bf6ec4afe04a1b0717fd5360cbb1a8d43.html. accessed by 29/11/2017) Halliday describes his grammar as built on the work of Saussure, Louis Hjelmslev, Malinowski, J.R. Firth, and the Prague school linguists. In addition, he drew on the work of the American anthropological linguists Boas, Sapir and Whorf. His "main inspiration" was Firth, to whom he owes, among other things, the notion of language as system.(Halliday,1985) Among American linguists, Benjamin Lee Whorf had the most profound effect on my own

\footnotetext{
* Foundation for Independent Research Projects for Doctoral Students of Minzu University of China
} 
thinking. Whorf "showed how it is that human beings do not all mean alike, and how their unconscious ways of meaning are among the most significant manifestations of their culture" ( Halliday,1985) (Halliday and His Systemic Functional Grammar. https://www.docin.com/touch/detail.do?id=1790286222\&from=singlemessage. accessed by 29/11/2017) For Halliday, grammar is described as systems not as rules, on the basis that every grammatical structure involves a choice from a describable set of options. Language is thus a meaning potential. Grammarians in SF tradition use system networks to map the available options in a language. In relation to English, for instance, Halliday has described systems such as mood, agency, theme, etc. Halliday describes grammatical systems as closed, i.e. as having a finite set of options. By contrast, lexical sets are open systems, since new words come into a language all the time. (Haliday, 1961)These grammatical systems play a role in the constructure of meanings of different kinds. This is the basis of Halliday's claim that language is metafunctionally organized. He argues that the raison d'être of language is meaning in social life, and for this reason all languages have three kinds of semantic components. All languages have resources for construing experience (the ideational component), resources for enacting humans' diverse and complex social relations (the interpersonal component), and resources for enabling these two kinds of meanings to come together in coherent text (the textual function). (Halliday, 1985) Each of the grammatical systems proposed by Halliday are related to these metafunctions. For instance, the grammatical system of 'mood' is considered to be centrally related to the expression of interpersonal meanings, 'process type' to the expression of experiential meanings, and 'theme' to the expression of textual meanings. Halliday refers to his functions of language as metafunctions. He proposes three general functions: the ideational metafunction, the interpersonal metafunction and the textual metafunction. The ideational metafunction is the function for construing human experience. (Systemic Functional Grammar. https://www.doc88.com/p-271407208775.html. accessed by 29/11/2017.) It reflects the contextual value of "field", that is, the nature of the social process in which the language is implicated. (Halliday, 1985) The interpersonal metafunction relates to a text's aspects of tenor or interactivity. Like field, tenor comprises three component areas: the speaker/writerpersona, social distance, and relative social statures. (Halliday and His Systemic Functional Grammar. https://www.docin.com/touch/detail.do?id=1790286222\&from=singlemessage. accessed by 29/11/2017) The textual metafunction relates to mode; the internal organization and communicative nature of a text. Systemic functional grammar grammar deals with all of these areas of meaning equally within the grammatical system itself. (Systemic Functional Grammar. https://wenku.baidu.com/view/94fd85370b4c2e3f572763e6.html. accessed by 29/11/2017)

\section{B. Introduction to Discourse Analysis}

The approach of analysis developed in discourse analysis and discursive psychology has been partly a product of the conception of human action. This conception emphasis the following features- action orientation: Discourse is the primary medium of human action and interaction. Action are not merely free standing but are typically embedded in broader practices. Some actions are Generic (e.g. Making invitation) and some are specific to the settings ( e.g. Air traffic control management of flight crew). Action orientation discourages the expectation that analysis discovers a one to one relationship between discrete acts and certain verbs. Situation - There are altogether three senses in which discourse is situated. First is the sequential organization so that the basic environment of what is being said is what has been said just before that, but this setup does not determine what is next to come. Second is the institutional location in which the tasks and identities of institution are relevant to what takes place. Third, it can be situated rhetorically, such that the descriptions may resist actual or potential attempts to counter them as interested. Construction - Discourse is constructive as well as constructed. It is constructed from various resources such as words, categories, commonplace ideas and broader explanatory systems. It is constructive in the sense that versions of the world, of events and actions, and of people's phenomenological worlds are built and stabilized in talk in the course of action. A person may explain not making an urgent call intentionally by saying that the number was unreachable or of his own faulty cognitive processing. Although these principles appear to be abstract but these are developed through analysis as well as theoretical practices. Rather than being the start, action orientation is often the endpoint of analysis. In action orientation to understand what is going on it is important to understand the talk in terms of the way it is situated. The rhetorical character of the talk is one of the features of discourse that is to be revealed through analysis. (Halliday and His Systemic Functional Grammar. https://www.docin.com/touch/detail.do?id=1790286222\&from=singlemessage. accessed by 29/11/2017 )

\section{ANALYSIS OF Discourse “HEAL THE WORLD”}

\section{A. Application of Person System in Analysis of Discourse "Heal the World"}

There's a place in your heart

And I know that it is love

And this place could be much

Brighter than tomorrow

And if you really try

You'll find there's no need to cry

In this place you'll feel

There's no hurt or sorrow 
There are ways to get there

If you care enough for the living

Make a little space

Make a better place ...

Heal the world

Make it a better place

For you and for me

And the entire human race

There are people dying

If you care enough for the living

Make it a better place...... (Heal the World There's a Place in Your Heart and I know that It Is. http://www.docin.com/p-441700256.html. accessed by 29/11/2017)

The lyrics above are just a part of "Heal the world". Application of the person system in the lyric discourse is widespread, and its implementation mainly depends on the person pronoun system. The author statistics that situation of application of the person pronoun in the lyric discourse "Heal the World", and find that uses of the first-person pronoun in the lyrics are eighteen times, and uses of the second person pronoun are eleven times, and uses of the third-person pronouns are six times. We can see that uses of the first and second person in the lyrics are clearly dominant. Below the author will discuss usage of person pronoun in the specific lyrics "Heal the world".

a. The use of the first-person pronoun in analysis of "Heal the World"

There appears several first-person pronouns such as "I", "we", "our", "us", "me", "my" in lyrics. Usage of "We" is the highest frequency, and there has been ten times; followed by is "me", which appears twice. "I" and "my" each appear twice. "our" and "us" each appear once. Such as:"We could fly so high" "Let our spirits never die" "In my heart I feel you are all my brothers" "Love's enough for us growing". ( "Heal the World" There's a Place in Your Heart and I know that It Is, http://www.docin.com/p-441700256.html. accessed by 29/11/2017.) We can see that creators use"we" many times, and they are trying to take every listener into the song, and let them feel that they are a part of it, and they speaks their own affairs, and make them immerses in this feeling. So they are inspired by passion in their hearts. They take some actions to protect the earth and to save their homes.

b. The use of the second-person pronoun in analysis of "Heal the World"

There appears the two second-person pronouns "you" and "your" in lyrics, where "you" appears 10 times, and "your" appears once. Such as: "There's a place in your heart" "In this place you'll feel there's no hurt or sorrow". The use of the second person pronoun allows the listener to feel intimate relationship, introducing them into specific scenarios of lyrics; they do not consciously equate themselves to "you" in a song in the process of listening to music. So they can more actively ground into the atmosphere of lyrics.

c. The use of the third person pronoun in analysis of "Heal the World"

"It" and "their" are the third person pronouns used in the lyrics of this song, such as: "Heal the world" "Make it a better place" "Together we'll cry happy tears" "see the nations turn theirs words into plowshares". The third person pronoun in this song is mainly used to refer to thing, and including former reference and backing reference. In the later analysis of cohesion system used in the lyrics it will be specifically explained.

\section{B. The Use of Mood System in Analysis of "Heal the World"}

Halliday believes that there are two kinds of basic role of language: giving and requirements (Halliday, 1994: 68). Lyrics of charity song may reflect the two roles of languages. On one hand the listener is given the message of lyrics; on the other hand, the listener is required to take action to respond to the call. These two effects of charity song is closely linked to the mood system. Tone system is an effective tool for discourse analysis of lyrics. The author inspects mood system mainly from the perspective of syntactic and focuses on statement mood, question mood, and imperative mood in the lyrics. Through analysis I found statement mood and the imperative mood are mainly used in this lyrics of song, and interrogative mood is used only for once. "There's a place in your heart And I know that it is love" "Heal the world" "Make it a better place" "Then why do we keep strangling life" "wound this earth, Crucify its soul"? ("Heal the World" There's a place in Your Heart and I know that It Is. http://www.docin.com/p-441700256.html. accessed by 29/11/2017) Declarative mood, imperative mood and interrogative mood are respectively used in three sentences. "Heal the World" is a song about charity, so the creator mainly uses indicative mood to tell the listener that his deep concern about this state of the world, and sketches out a better world to make the language more persuasive. In the whole song use of imperative mood greatly enhances the appeal of the song. Which can evoke a sense of responsibility in mind of listeners, and make them act to create a better world for people around the world. The lyric which uses interrogative mood not only can express thoughts and feelings of creators but also allows listeners to reflect on their behaviors and realize the truth.

\section{The Use of Cohesion System in Analysis of "Heal the World"}

Halliday divides cohesion into grammatical cohesion and lexical cohesion. Grammatical cohesion can be divided into coordinate, omissions, substitutions and connection. Lexical cohesion can be divided into repetition, synonym / antonym, hyponymy /part-whole relationship and collocation.(Zhuanglin $\mathrm{Hu}, 2005$ ) The author will analyze lyrics of 
this song from aspects of coordination, connection and repeat. Coordination can be divided into two types: inner reference and outer reference. Inner reference can be divided into former reference and backing reference. Coordination: Coordination often appears in English lyric discourse. Such as: "Heal the world" "Make it a better place" "And the dream we were conceived in will reveal a joyful face" ("Heal the World" There's a Place in Your heart and I know that it is. http://www.docin.com/p-441700256.html. accessed by 29/11/2017.) In the above example the case ten is the former reference, and the case eleven is the backing reference. In the case of ten "it" refers to "the world" ; in the case eleven "the dream" refers to the dream in our hearts. We can see that the use of coordination in the lyrics can make structure perfect and cohesion natural. Connection: There are a lot of conjunctions in English lyrics, which can not only make the songs become colloquial, but also make the song becomes smooth and consistency. For example: "We stop existing and start living" "Then it feels that always" The conjunction "then" is used in the case twelve, which makes cohesion of lyrics become coherent naturally and contacts sentences perfectly, so that the creator can express thoughts and feelings better. Repeat: The device "repeat" is often used in English lyrics. For example: "So make a better world" "Make a better world". The device "repeat" is used in lyrics. On one hand it can make melodies of lyrics beautiful, on the other hand it can deepen the theme of song and deepen the impression of listener to the song

\section{ANALYSIS OF DisCOURSE “THE MIDDLE EASTERN BAZAAR”}

Discourse:The Middle Eastern Bazaar takes you back hundred-even thousand-of years. The one I am thinking of particularly is entered by a Gothic arched gate way of aged brick and stone. You pass from the heat and glare of a big, open square into a cool, dark cavern which extends as far as the eye can see, losing itself in the shadowy distance. Little donkeys with harmonious tinkling bells thread their way among the throngs of people entering and leaving the bazaar. The road way is about twelve feet wide, but it is narrowed every few yards by little stalls where goods of every conceivable kind are sold. The din of the stall holders crying their wares, of donkey boys and porters clearing a way for themselves by shouting vigorously, and of would be purchasers arguing and bargaining is continuous and makes you dizzy. (The first paragraph) (Mei Renyi \& Wang Lili, 1995) (The Middle Eastern Bazaar http://www.doc88.com/p-9495492730979.html)

Objective analysis of discourse: see features of discourse from type of transitive verb process. Variables of situation context: Language Course: description of the Middle East market and activities on market; Tenor: The largest social distance between author and reader; language style: writing style of formal English. Analysis of types of transitive verb process: Transitivity system: There are six processes: physical process, mental process, verbal process, existential process, relational process; physical process can be subdivided into action process and event process. (Halliday, 1994):

\section{A. Analysis of Type of Verb Process in Discourse}

There are total of 21 verbs in this discourse. There are eleven material processes: the action process is used to describe actions as "entered", "pass", "leaving", "losing", "narrowed", "thread their way", "sold"; five verbal processes are used to describe noisy sound in market such as "din", "shouting", "bargaining", "crying", "arguing"; three relational processes are used to describe characteristics of the appearance and atmosphere of the market such as "is", "makes"; two mental processes are used to reflect the author's opinions about it such as "see" and "thinking of" .

\section{B. Comment on the Discourse}

The material process, action process, and verbal process are dominant in discourse, which is the main stylistic features of this discourse; in addition, because of the great social distance between the author and readers, and the formal writing in English, therefore some forms of the present participle of verbs are used. Twenty one verb processes, their participants and environmental factors are used to describe the characteristics of the Middle East market: a large of people and donkeys walk on the market, and in the bazaar people are busy in doing business, which is full of cries and bargaining sound of buyers and sellers. All in all these processes successfully reveals atmosphere full of vibrant and noisy sound here. Which is semantic characteristics of this discourse.

\section{ANALYSIS OF Discourse "BLACKMAIL"}

Duchess: "We will not pay you."(modulation: inclination: insisting)

Ogivile: "Listen, lady..."

Duchess: "I will not listen. (modulation: inclination: insisting)You will listen to me."(modulation: obligation: required)...

Duchess:We will not pay you ten thousand dollars. But we will pay you twenty thousand dollars(modulation: inclination: insisting)...

Duchess:You will drive our car north.(modulation: obligation: required) ( Mei Renyi \& Wang Lili, 1995)

Discourse Analysis Objective: To observe personality traits of the Duchess from the modality; Situation context variables: Language Course: events of blackmailing, crashing, and escaping: the accident car drives on the north and bargain; Tenor: The Duchess and who is a restaurant scout ; The duchess is a noble, who has a high social status, while Ogivile has a low social status. They have the largest social distance; Language style: dialogue between Duchess and restaurant scout, and Colloquial English; 


\section{A. Modality Component Analysis of Discourse}

Modality system: There are two options: the tendency or obligatory, there are three different levels of choice: high, medium, low. They are used to represent the speaker's attitude toward things. Modality component analysis of discourse: There are six components used to represent modality, such as "will", "will not", if other eight modality components associated with this discourse included in this text such as "want" "must" "never" intended, "decisively". There are a total of 14 components used to represent modality, and these components are used to represent restaurant scout's blackmail attitudes towards the event of the duchess and her husband's car crash and escape.

\section{B. Comments on the Discourse}

Extensive use of the modality components are stylistic features of this discourse. These modality components show that the duchess's imposing personality and the dominant share in the process of bargaining with restaurant scout. restaurant scout spotted her and her husband's behavior of escaping the car crash and wanted to blackmail ten thousand US dollars, but to his surprise, the Duchess said that she must give him twenty thousand Us dollars, but the condition is that they will drive their car to the north to escape police chase. Her condescending tone of command makes the restaurant scout gradually in a passive position. It can be clearly seen that "I, we will" and "you will" are suitable for haughty temperament of the duchess and very suitable for her attitude towards people because she is from a noble family. Her identity makes her not be at a disadvantage in any case. Therefore, the ingenious use of these modality components has successfully portrayed the smart character of Duchess, suggesting that she will be stronger than the restaurant scout in this bargain.

\section{ANALYSIS OF DisCOURSE “ThE SOUND OF MUSIC”}

Discourse:(Sister Margaretta Tells Maria that she is expected by the Reverend Mother in her office. Maria follows her in.)

Reverend Mother: You've been unhappy, I'm sorry.

Maria: Reverend Mother.

R.M.: Why did they send you back to us?

Maria: They didn't send me back, Mother. I left.

R.M.: Sit down, Maria. Tell me what happened.

Maria: Well, I ...I was frightened. R.M.: Frightened? Were they unkind to you? Maria: Oh, no .I was, I was confused. I felt...I never felt that way before. I couldn't stay-and I knew if I would be away from it, I'll be safe.

R.M.: Maria, our Abbey is not used to be as an escape. What is it that you can't face?

Maria: I can't face him again. R.M.: Him?(To Sister Margaretta) Thank you, Sister Margaretta. (Sister Margaretta leaves the room.)Captain Von Trapp? Are you in love with him?

Maria: I don't know, I don't know. The Baroness said I was. She said that he was in love with me, but I didn't want to believe it. Oh, there were times when we looked at each other. Oh, Mother, I could hardly breathe.

R.M.: Did you let him see how you felt?

Maria: If I did, I didn't know it. That's what's been torturing me. I was there on God's errand. To have asked for his love would have been wrong. I couldn't stay, I just couldn't. I am ready at this moment to take my vows. Please help me.

R.M.: Maria, the love of a man and a woman is holy too. You have a great capacity to love. What you must find out is how God wants you to spend your love.

Maria: But I've pledged my life to God. I've pledged my life to his service.

R.M.: My daughter, if you love this man, it doesn't mean you love Godless. Now you must find out. You must go back. Maria: Oh, Mother, you can't ask me to do that. Please let me stay. I beg you.

R.M.: Maria, these walls were not built to

Shut out problems. You have to face them. You have to live the life you were born to live.( Then sings the song "Climb Every Mountain") (Fang Yanetal.2001:829)

Objective Analysis of Discourse : Observe how the Reverend Mother persuades Maria to return to captain von Trapp and the Reverend Mother's personality traits from perspective of use of the mood and modality. Situation context variables: Language Course: Maria comes back to monastery and Reverend Mother talks to her;

Tenor: Maria had resigned and was no longer a tutor. She hopes to become a nun. The Reverend Mother is a bit elderly, who held the highest office in the monastery; the nuns in monastery seem to live in a big family, and there are social distance between them but relatively close; Language style: dialogue between Maria and the Reverend Mother, colloquial English;

\section{A. Mood and Modality Analysis of Discourse}

Mood system: there are differences between an indicative mood and imperative mood at the first level. If you choose indicative mood, you can further choose narrative mood or question mood. If you choose imperative mood, you may further choose whether it includes speakers or not. In each case the speaker and the hearer play different roles, and they are responsible for different social functions, as shown in Following Mood and modality of discourse analysis: During this conversation the Reverend Mother uses two imperative sentences such as "Sit down, please". "Tell me what 
happened", and eight interrogative sentences. Modal verb are used for the five times in the discourse, Including "must" which is used for three times, and "have to" which is used for two times.

\section{B. Comments on the Discourse}

Imperative sentences, a lot of interrogative sentences, and modal verbs are used in discourse, which are the stylistic features of the discourse. Reverend Mother uses two imperative sentences and eight interrogative sentences. Maria is the performer to actions and the respondent to issues, indicating that social status of these two people who participated in the dialogue is not the same: Reverend Mother is dean of monastery, who has the great powers; Maria is a trainee nun, who is at a lower position. Through two moods Reverend Mother controls the content and direction of their dialogue. Through these eight questions she knows the Maria's psychology activities and understand the cause of her distress.

This is language function of these two moods in discourse. At the same time they are living in the monastery where seems a large family, so they are relatively close to each other, for example they call each other "mother" and "daughter". Maria told Reverend Mother secrets of her love with Von Trapp. Thus we can say that because of uses of the two moods and the related vocabulary the author successfully portrays the characters and qualities of a din of monastery, who is kind and has a wealth of experience. In addition uses of imperative moods and modal verbs "must" "have to" i reveals another meaning of the dialogue: Although Reverend Mother's words are very friendly, but her words have the authority. Her voice makes Maria felt that she was speaking on behalf of God, and therefore she must obey the will of God to come back to the Von Trapp.

\section{CONCLUSION}

Through analysis of several different discourse, we can draw two conclusions: firstly, Through the analysis the author found that the appropriate use of person system and mood system can shorten the distance between creators and listeners to raise so as to improve nature of dialogue of discourse; appropriate use of cohesion can make the transition of discourse become natural so as to help creators to better express thoughts and feelings. In short, the systemic functional grammar provides a viable theoretical framework for discourse analysis. Halliday's Systemic Functional Grammar framework can be used to reveal the deeper meaning of the discourse. It also can be used to understand and explain the semantics of discourse and stylistic features, which is not only very important for the interpretation and appreciation of discourses, but also it has practical value on the English teaching of reading comprehension; secondly, "context - text comment" mode of systemic functional linguistics used to analyze discourse is feasible. Explore it has some practical significance

\section{REFERENCES}

[1] Cummings. M.D.U. (1983). Simmons. The Language of Literature. Oxford: Pergamon Press.

[2] Halliday. J. (1994). M.A.K. An Introduction to Functional Grammar. London: Edward Amold.

[3] Halliday. M. (2000). M.A.K. An Introduction to Functional Grammar. London: Edward Arnold Publisher.

[4] Halliday and His Systemic Functional Grammar. https://www.docin.com/touch/detail.do?id=1790286222\&from=singlemessage. accessed by 29/11/2017.

[5] Halliday and His Systemic Functional Grammar. https://www.docin.com/touch/detail.do?id=1790286222\&from=singlemessage. accessed by 29/11/2017.

[6] Heal the World There's a Place in Your Heart and I know that It Is. http://www.docin.com/p-441700256.html. accessed by 29/11/2017.

[7] Huang Guowen. M. (2001). The Theory and Practice of Discourse Analysis. Shanghai: Shanghai Foreign Language Education Press.

[8] Huang Xiaorong. J. (2009). On Grammatical Cohesion of Lyrics in English Songs. Journal of Liuzhou Vocational \& Technical College (Vol.9), 2, 89-92.

[9] Hu Zhuanglin, M. (2005). Zhu Yongsheng, Zhang Delu,\&Li Zhanzi. Introduction to Systemic Functional Linguistics. Beijing: Peking University Press.

[10] Li Zhanzi. M. (2002). A Study of Interpersonal Meaning of Discourse. Shanghai: Shanghai Foreign Language Education Press.

[11] Systemic Functional Grammar. https://wenku.baidu.com/view/912fb66bf6ec4afe04a1b0717fd5360cbb1a8d43.html. accessed by $29 / 11 / 2017$.

[12] Systemic Functional Grammar. https://wenku.baidu.com/view/94fd85370b4c2e3f572763e6.html. accessed by 29/11/2017.

[13] The Middle Eastern Bazaar. http://www.doc88.com/p-9495492730979.html. accessed by 29/11/2017.

[14] Zhao She. D. (2007). Mood System and Interpersonal Functions in English Love Song Lyrics. Chang Chun: Northeast Normal University.

Xiaqing $\mathbf{L i}$ is a Doctor degree candidate in the Department of Minority Languages and Literature at Minzu University of China in capital city Beijing, in China, where she is pursuing her Doctor's degree in linguistics and applied linguistics. Her research interests include computational linguistics, and applied linguistics. 